\title{
MORALIDADE, DISCRICIONARIEDADE E OS LIMITES DA FUNÇÃO JURISDICIONAL NO CONTEXTO DO ESTADO DEMOCRÁTICO DE DIREITO: O CASO DA SÚMULA VINCULANTE No 13 NO BRASIL.
}

\begin{abstract}
Alexandre Travessoni Gomes Trivisonno*1 Alice de Siqueira Khouri**

\section{Resumo}

O presente artigo se dedica ao estudo da tensão entre a segurança e a correção das decisões judiciais, especificamente com relação ao princípio da moralidade que possui grande indeterminação jusfilosófica no momento de sua aplicação. Estuda-se neste ensaio a flexibilidade do princípio da moralidade que implica um espaço para a discricionariedade judicial tendente ao arbítrio na medida em que extrapola os limites impostos pela separação de poderes em um estado que se intitule democrático de direito. Referida análise é concluída com o exemplo concreto da Súmula Vinculante ${ }^{\circ}{ }^{13}$, editada pelo Supremo Tribunal Federal no Brasil.
\end{abstract}

Palavras-chave: Moralidade. Discricionariedade judicial. Separação de poderes. Súmula Vinculante. Estado Democrático de Direito.

\section{MORALITY, DISCRETION AND THE LIMITS OF THE JURISDICTIONAL FUNCTION IN THE CONTEXT OF THE DEMOCRATIC STATE OF LAW: THE CASE OF BINDING PREDICTION \#13 IN BRAZIL.}

\begin{abstract}
This article deals with the tension between security and the correctness of judicial decisions, specifically regarding to the principle of morality, which has great indeterminacy at the time of its application. This essay deals with the flexibility of the principle of morality, which implies a space for judicial discretion in favor of arbitrariness insofar as it goes beyond the limits imposed by the separation of powers in a state that is democratic in law. The aforementioned analysis finds a concrete example in Binding Precedent \#13, edited by the Federal Supreme Court in Brazil
\end{abstract}

\footnotetext{
1 * Alexandre Travessoni Gomes Trivisonno é Doutor em Direito pela Universidade Federal de Minas Gerais (área de concentração em Filosofia do Direito) (2002). Realizou, sob o patrocínio do DAAD, pesquisa (Pós-Doutorado) no Instituto de Filosofia da Universidade de Saarland (Alemanha-2005). Foi pesquisador visitante no Instituto Max Planck de Direito Internacional Público e Direito Comparado de Heidelberg (Alemanha - 2006-2007) e desenvolveu, em 2010-2011, 2012 e 2013, sob patrocínio da Fundação Alexander von Humboldt, pesquisa (PósDoutorado) na Cátedra de Filosofia do Direito e Direito Público da Universidade de Kiel (Alemanha), sob supervisão do Prof. Dr. Robert Alexy. E-mail: a.travessoni@gmail.com.

** Alice de Siqueira Khouri é Mestre em Direito Público pela Pontifícia Universidade Católica de Minas Gerais - PUC MG (2017). É autora do livro "Súmula Vinculante no 13 e o STF: um caso de ativismo?. 1. ed. Belo Horizonte: D'Plácido, 2017. v. 1. 209p". Parecerista ad hoc da Revista de Direito Administrativo e Infraestrutura - RDAI, do conselho editorial da Revista dos Tribunais. E-mail: alicekhouri@gmail.com. Endereço: Rua Bernardo Figueiredo, $n^{\circ}$ 104/1202, Serra. CEP 30.220-140.
} 
Keywords: Morality. Judicial discretion. Separation of powers. Binding Precedents. Democratic State.

\section{Introdução}

A natureza e os limites da atividade jurisdicional, sobretudo em um estado de direito democrático, constitui um dos temas de maior relevância no âmbito da teoria do direito atual. Nela se contrapõem, de um lado, a segurança jurídica, ou seja, observar o que a lei determina, e, de outro, a correção das decisões, que implica possuir o aplicador uma certa margem de manobra que possibilite adequar as previsões gerais da lei aos casos concretos.

A dicotomia ativismo judicial $x$ autocontenção não mais é suficiente para estabelecer os contornos da atividade judicial no contexto democrático contemporâneo, pois a complexidade e diversidade das situações vem exigindo, cada vez mais, um debate sofisticado acerca dos limites e alcances da atividade jurisdicional e da discricionariedade judicial. Isso ocorre porque embora existam casos em que a lei é clara e a solução é, de fato, uma interpretação fiel, sistêmica e coerente do arcabouço legislativo, não são poucos os momentos em que o julgador se depara com a textura aberta do direito, bem como com lacunas e antinomias jurídicas que exigem grande esforço interpretativo do juiz para que as soluções sejam encontradas e direitos sejam efetivados através do provimento judicial. Considerando a lei e os limites do poder judiciário, sobretudo em um cenário democrático que preza pela separação de funções ou poderes como forma de coibir abuso e concentração de poder, surge, nesses casos, o problema do limite da discricionariedade do juiz e do alcance de sua função jurisdicional

Este artigo se dedica a aprofundar o estudo da tensão entre a segurança e a correção das decisões judiciais, especificamente com relação ao princípio da moralidade que, por ser uma norma que possui textura, possui grande indeterminação no momento de sua aplicação. A flexibilidade do princípio da moralidade implica um espaço para a discricionariedade judicial que, no nosso entendimento, não pode nunca ser arbitrária ou extrapolar os limites impostos pela separação de poderes em um estado que se intitule democrático de direito.

Como exemplo da atividade jurisdicional que extrapola suas funções valendo-se de um princípio aberto e vago como o da moralidade e, assim, viola limites democráticos, cita-se, no caso brasileiro, a súmula vinculante $n^{\circ} 13$ (SV 13), editada, em 2008, pelo Supremo Tribunal 
Federal (STF), com o intuito de proibir, por meio do verbete, a indicação de parentes ou afins para cargos de confiança na Administração Pública. ${ }^{2}$

O conteúdo da SV 13 origina-se da atividade jurisdicional que representou o posicionamento do órgão máximo do poder judiciário brasileiro em relação a uma prática, até então sequer definida pela ciência do direito, conhecida por muitos como nepotismo, e que fora abordada pela primeira vez quando da edição da Resolução $n^{\circ}$ 07, de 18 de outubro de 2005, do Conselho Nacional de Justiça (CNJ).

Com o advento da súmula vinculante $\mathrm{n}^{\circ} 13$ surgiu a seguinte questão jurídica: a liberdade de nomeação e exoneração dos cargos de confiança, expressamente previstas pela Constituição da República de 1988 (art. 37, II), cujas restrições foram reservadas à lei infraconstitucional, poderia ser limitada por atividade jurisdicional?

A justificativa para a edição da súmula, em consonância com a linha de defesa que responde "sim" à questão colocada, repousa no argumento central de que o princípio da moralidade, contido no caput do artigo 37 da Constituição, autorizaria a limitação da liberdade constitucional de nomeação dos cargos de confiança, visto que a prática de indicação de parentes e afins representaria necessária violação à moralidade.

Segundo esse raciocínio, o poder judiciário estaria autorizado a fazer exceções à regra constitucional que elevou a matéria à competência disciplinar da lei, permitindo, assim, que a limitação da liberdade constitucional de nomeação fosse feita através da atividade jurisdicional. Assumiu-se, nesse caso, um amplo espaço de discricionariedade judicial mediante invocação do princípio da moralidade, em um esforço hermenêutico que pretendemos analisar adiante.

Considerando a tensão mencionada acima, bem como o fato de que a justificativa material da súmula vinculante $\mathrm{n}^{\mathrm{o}} 13$ foi a suposta violação ao princípio da moralidade, o presente estudo desenvolve-se em três momentos: inicialmente, serão feitas considerações sobre a discricionariedade no direito e suas implicações jurídico-filosóficas; em um segundo momento, será abordado o princípio da moralidade e os problemas por trás de seu sentido jurídico; finalmente, na conclusão, serão abordados os problemas que a vagueza do princíoio da moralidade traz, sobretudo em sua aplicação jurisdicional.

\footnotetext{
${ }^{2}$ Nas exatas palavras que foram eleitas após o consenso entre os ministros componentes do STF, à época: “A nomeação de cônjuge, companheiro ou parente em linha reta, colateral ou por afinidade, até o terceiro grau, inclusive, da autoridade nomeante ou de servidor da mesma pessoa jurídica investido em cargo de direção, chefia ou assessoramento, para o exercício de cargo em comissão ou de confiança ou, ainda, de função gratificada na administração pública direta e indireta em qualquer dos poderes da União, dos Estados, do Distrito Federal e dos Municípios, compreendido o ajuste mediante designações recíprocas, viola a Constituição Federal." (BRASIL, 2008c).
} 
Pretendemos, com o presente estudo, contribuir para o debate acerca dos limites da discrionariedade judicial, através de uma comprometida visão de jurisdição constitucional democrática, ressaltando, desde já, que o tema comporta diversas abordagens e pontos de vista que não pretendemos abordar neste estudo.

Esclarecemos que nosso estudo propõe uma visão crítica e ainda incipiente na doutrina sobre o ativismo judicial, que constitui um assunto polêmico e delicado, sobretudo no atual panorama científico do direito, que procura substituir um legalismo supostamente defendido pelo positivismo jurídico pelo apego às decisões judiciais e pela mitificação do poder judiciário, alcançando um suposto ponto de equilíbrio da função estatal diante da omissão constante do legislativo.

\section{Discricionariedade}

Para compreendermos os elementos centrais da discricionariedade no direito, abordaremos as teorias de Kelsen, Hart e Alexy sobre o tema, que foram analisadas em dois trabalhos produzidos por Trivisonno: Princípios Jurídicos e Positivismo Jurídico: As Críticas de Dworkin a Hart se Aplicam a Kelsen e A Distinção entre Discricionariedades Legislativa e Judicial: uma Proposta a Partir das Teorias de Kelsen e Alexy. ${ }^{3}$

\subsection{Discricionariedade em Kelsen e Hart}

A fim de se compreender o sentido de discricionariedade em Kelsen é preciso começar com a distinção feita por ele entre legislação e jurisdição. Em Kelsen, a distinção entre legislação e jurisdição é meramente quantitativa, ou seja, uma questão de grau. Kelsen rejeita aquilo que ele denomina a noção tradicional, segundo a qual o legislativo cria normas, enquanto o juiz as aplica. Para ele, tanto legislação quanto jurisdição compreendem, ao mesmo tempo, criação e aplicação de normas: quando o legislador cria uma lei ele aplica a constituição, e quando o juiz aplica as leis ele cria uma norma individual (uma sentença). ${ }^{4}$

\footnotetext{
${ }^{3}$ Cf. TRIVISONNO, Alexandre Travessoni Gomes, Princípios Jurídicos e Positivismo Jurídico: As Críticas de Dworkin a Hart se Aplicam a Kelsen, in: Hans Kelsen, Teoria Jurídica e Política, A. T. G. Trivisonno e J. A. De Oliveira (orgs.), Rio de Janeiro: Forense Universitária, 2013, p. 185-212 e TRIVISONNO, Alexandre Travessoni Gomes, A Distinção entre Discricionariedades Legislativa e Judicial: uma Proposta a Partir das Teorias de Kelsen e Alexy (no prelo).

${ }^{4}$ KELSEN, Hans, Reine Rechtslehre, $2^{\mathrm{a}}$ ed., 346 ff. ; Teoria Pura do Direito, 363 ff.
} 
A criação de uma norma é relativamente determinada pela norma superior, e, assim, relativamente indeterminada. A margem de manobra do legislador, segundo Kelsen, é mais ampla que a do juiz, mas em ambos os casos não se pode deduzir, da norma superior (ou de um grupo de normas superiores), apenas uma norma inferior. Em síntese, uma vez que a partir da constituição não se pode deduzir apenas uma norma geral sobre uma matéria (ou seja, apenas uma lei), e uma vez que a partir de leis não se pode deduzir apenas uma decisão para um caso (apenas uma sentença), tanto o legislador quanto o juiz possuem discricionariedade. Já que o juiz está vinculado às leis que o legislador cria, a discricionariedade do juiz é menor que a do legislador, e a distinção entre legislação e jurisdição é uma questão de grau.

Embora não desenvolva uma distinção clara entre legislação e jurisdição, a concepção de Hart sobre a discricionariedade judicial é, em nosso entendimento, semelhante à de Kelsen. Ele afirma que o direito possui textura aberta, e isso significa haver casos em que muito deve ser desenvolvido pelas cortes, que devem ponderar interesses que se chocam e variam de peso caso a caso. ${ }^{5}$ Ao tratar da aplicação das regras jurídicas, após descrever a aplicação das regras de um jogo, ele adiciona que a textura aberta do direito deixa às cortes um poder criativo maior do que aquele atribuído aos marcadores (de um jogo), cujas decisões não são usadas como precedentes. ${ }^{6}$ Além disso, no Pós-escrito de $O$ Conceito de Direito, respondendo às críticas de Dworkin, ele reafirma sua posição, afirmando que há pontos em que o direito existente falha em determinar uma decisão correta, e a fim de decidir tais casos o juiz deve exercer seu poder de criação do direito. ${ }^{7}$

A generalidade (ou textura aberta) é pois, tanto para Kelsen quanto para Hart, a principal causa do poder discricionário. A natureza da linguagem (jurídica) torna impossível que uma norma preveja todos os detalhes de um comportamento, deixando portanto sempre ao aplicador uma margem para decidir. Mas deve ser enfatizado que o poder discricionário não significa, para ambos, que a decisão possa ser arbitrária: a indeterminação é relativa e o juiz deve apresentar razões para a decisão.

\subsection{Discricionariedade judicial na Teoria Discursiva do Direito de Alexy}

\footnotetext{
${ }^{5}$ HART, Herbert. L. A. The Concept of Law, $2^{\text {nd }}$ ed. Oxfor: Oxford Universtiy Press, 1994, 135.

${ }^{6}$ HART, The Concept of Law, 145.

${ }^{7}$ HART, The Concept of Law, 273.
} 
A questão da aplicação judicial do direito foi abordada, por Alexy, na Teoria da Argumentação Jurídica. ${ }^{8}$ Assim, uma análise de seus principais elementos, especialmente de sua tese principal, a tese do caso especial, será útil para podermos compreender o núcleo do pensamento de Alexy sobre a discricionariedade judicial. Com sua Teoria da Argumentação Jurídica, Alexy procura desenvolver uma metodologia da aplicação jurídica que vá além da mera subsunção, que, segundo Alexy, não pode ser usada como metodologia da aplicação do direito, em virtude de quatro razões: (i) a vagueza do direito, (ii) a possibilidade de conflitos entre normas, (iii) a existência de casos para os quais não pode ser encontrada uma norma jurídica e (iv) a necessidade de decisões contra legem. ${ }^{9}$

Alexy critica a concepção de Kelsen sobre a racionalidade no direito e, desse modo embora não diretamente - a concepção de Kelsen sobre legislação e jurisdição apresentada acima. Em uma significativa nota de rodapé Alexy afirma que a limitação da ciência do direito a uma tarefa de meramente conhecer e descrever normas positivas, apontando seus possíveis significados em casos concretos, deve-se ao fato de Kelsen acreditar ser impossível, no âmbito da ciência do direito, o controle racional de juízos de valor. A tese da Teoria da Argumentação Jurídica é que Kelsen está errado, e somente se ele estiver errado se justifica falar em uma ciência do direito mais ampla, ou seja, uma ciência do direito que não se limite à mera descrição de normas positivas. ${ }^{10}$

Embora Alexy não negue explicitamente a discricionariedade judicial, essas suas palavras mencionadas no parágrafo anterior parecem, a nosso ver, uma negação da tese da discricionariedade de Kelsen. A relatividade de juízos de valor, que levou Kelsen a defender tanto a discricionariedade legislativa quanto a discricionariedade judicial é contrastada, em Alexy, a um certo grau de objetividade, que permite a defesa de que juízos de valor são racionais na medida em podem ser racionalmente fundamentados. Esse certo grau de objetividade possibilitará a Alexy apontar, dentre as várias possíveis interpretações do direito em um caso concreto, algumas opções que devem se tornar, usando as palavras de Kelsen, normas individuais. Em síntese, para Alexy, juízos normativos concretos podem ser justificados na medida em que podem ser fundamentados racionalmente.

\footnotetext{
${ }^{8}$ ALEXY, Robert, Theorie der juristischen Argumentation - Die Theorie des rationalen Diskurses als Theorie der juristischen Begründung, Frankfurt a. M.: Suhrkamp, 1978 (reimpressão em 1983; 3. edição 1996, usada para as citações neste trabalho),

${ }^{9}$ ALEXY, Theorie der juristischen Argumentation, $17 \mathrm{f} \mathrm{s}$.

${ }^{10}$ ALEXY, Theorie der juristischen Argumentation, 264, n. 6.
} 
A fim de se alcançar essa racionalidade, Alexy desenvolve um modelo de aplicação do direito no qual o discurso jurídico (ou argumentação jurídica) é um caso especial do discurso prático geral (ou argumentação prática geral). Isso significa que o discurso jurídico possui algumas características em comum com o discurso prático geral, mas também algumas características específicas, que o discurso prático geral não possui. As características comuns que ambos discursos possuem se revelam pelo fato de tanto o discurso prático geral quanto o discurso jurídico dizerem respeito a questões práticas, ou seja, questões sobre o que deve ser feito ou omitido, e pelo fato de ambos levantarem uma pretensão de correção. As características específicas do discurso jurídicos são suas vinculações ao direito válido, ou seja, à lei, a precedentes e à dogmática jurídica. ${ }^{11}$

Mas quais são exatamente as características do discurso prático geral? Uma análise da resposta de Alexy a uma das objeções apresentadas por Habermas contra sua teoria fornece a resposta a essa pergunta. Em Direito e Democracia - entre Facticidade e Validade, Habermas critica a tese do caso especial, afirmando que o discurso jurídico não deveria ser considerado um tipo de discurso moral. ${ }^{12}$ Em sua resposta, Alexy explica que sua tese não é a de que o discurso jurídico é um caso especial do discurso moral, como definido por Habermas, mas antes um caso especial do discurso prático geral. O discurso prático geral não é a mesma coisa que o discurso moral no sentido de Habermas, afirma Alexy: "ele é um discurso em que questões e razões morais, éticas e pragmáticas se conectam". ${ }^{13}$ Alexy recorda que razões morais, no sentido de Habermas, são razões relacionadas à igual consideração dada a interesses de todos os seres humanos, dizendo respeito, para Habermas, a "universalização e somente a universalização". ${ }^{14}$ Razões ético-políticas, como afirma Habermas, dizem respeito a nossa auto-compreensão coletiva implícita em nossas tradições e avaliações, ${ }^{15}$ enquanto razões pragmáticas dizem respeito à adequação de meios para a realização de certos objetivos, bem como à ponderação de interesses e compromissos. ${ }^{16}$ Assim, na teoria de Alexy, "a

\footnotetext{
${ }^{11}$ ALEXY, Theorie der juristischen Argumentation, 32, 38, 263.

${ }^{12}$ HABERMAS, Jürgen, Faktizität und Geltung - Beiträge zur Diskurstheorie des Rechts und des demokratischen Rechtsstaats. Frankfurt a. M.: Suhrkamp, 1992, 283.

${ }^{13}$ ALEXY, Robert, The Special Case Thesis, in: Ratio Juris 12, 4 (1999), 374-384, 378; tradução em português: A Tese do Caso Especial, A. T. G. Trivisonno (trad.), in: Teoria Discursiva do Direito, A. T. G. Trivisonno (org.). Rio de Janeiro: Forense Universitária, 2014, 91-106.

${ }^{14}$ ALEXY, The Special Case Thesis, 377.

${ }^{15}$ HABERMAS, Faktizität und Geltung, 139.

${ }^{16}$ HABERMAS, Faktizität und Geltung 197.
} 
argumentação jurídica está aberta não somente a razões morais (...), mas também a razões ético-políticas e pragmáticas". ${ }^{17}$

Em síntese, a tese do caso especial não afirma que o discurso jurídico é um caso especial do discurso moral, mas antes do discurso prático geral, que inclui razões morais, éticopolíticas e pragmáticas. O discurso moral é, portanto, uma parte do discurso prático geral.

Após a publicação de sua Teoria da Argumentação Jurídica, Alexy abordou, em três diferentes escritos, a questão sobre se há uma única resposta para toda questão jurídica. $\mathrm{O}$ primeiro é o ensaio Diskurstheorie und Rechtssystem ${ }^{18}$ (Teoria do Discurso e Sistema Jurídico), publicado em 1987, em que ele afirma que deve ficar "aberto se, sob uma idealização completa, existe exatamente uma resposta correta para toda questão". ${ }^{19}$ Segundo Alexy, defender a ideia de que há uma única resposta para toda questão prática significa conectar o conceito de procedimento com o conceito de uma correção absoluta. Ele adota então um modelo que também conecta correção e procedimento, mas no qual o conceito de correção é relativo, porque depende do discurso real, e no qual o conceito de uma correção absoluta é uma ideia regulativa. ${ }^{20} \mathrm{O}$ segundo escrito é o Pós-escrito da segunda edição alemã da Teoria da Argumentação Jurídica, publicada em 1991, em que Alexy afirma que do cumprimento das exigências do discurso ideal não se segue logicamente que no discurso ideal haja apenas uma única resposta para toda questão prática. Ele também afirma que a tese da única resposta correta constitui uma suposição forte que possui mais desvantagens do que vantagens. Contudo, ele aceita seu papel como uma ideia regulativa, ou seja, algo que de fato nem sempre existe, mas que deve ser almejado. ${ }^{21} \mathrm{O}$ terceiro escrito em que Alexy aborda diretamente essa questão é Law, Discourse and Time (1995) (Direito, discurso e tempo), em que ele a denomina "problema do conhecimento prático" e reafirma que, mesmo sob as condições do discurso ideal, não se pode ter certeza que uma única resposta correta para toda questão prática pode ser encontrada. ${ }^{22}$ O que Alexy quer dizer quando afirma que a única resposta deve permanecer como uma ideia regulativa? Ele quer dizer que o legislador, o juiz ou ambos devem representá-la

\footnotetext{
${ }^{17}$ ALEXY, The Special Case Thesis, 377.

${ }^{18}$ ALEXY, Robert, Diskurstheorie und Rechtssystem, in: Synthesis philosophica 5 (1988), 299-310, publicado originalmente em croata, Teorija diskursa i pravni sistem, Maja Uzelac (trans.) Filozofska istrazivanja 20 (1987), 185-194; tradução em português: Teoria do Discurso e Sistema Jurídico, A. T. G. Trivisonno (trad.), in: Teoria Discursiva do Direito, A. T. G. Trivisonno (org.). Rio de Janeiro: Forense Universitária, 2014, 75-89.

${ }^{19}$ ALEXY, Diskurstheorie und Rechtssystem, 304-305.

${ }^{20}$ ALEXY, Diskurstheorie und Rechtssystem, 304-305; Teoria do Discurso e Sistema Jurídico, 83.

${ }^{21}$ ALEXY, Theorie der juristischen Argumentation, Nachwort, 413-414.

22 ALEXY, Robert, Law, Discourse and Time, in: ARSP 64 (1995), 101-110, 108.
} 
como um objetivo? Parece claro que ele quer dizer que o juiz deve representá-la como objetivo, por duas razões. A primeira é que, em seus escritos iniciais, especialmente na Teoria da Argumentação Jurídica, ele se concentra na figura do juiz, na correção das decisões judiciais e portanto na aplicação do direito em juízo. A segunda razão, que se relaciona à primeira, é que nos escritos acima mencionados ele discute a tese da única resposta, de Ronald Dworkin, que foi uma tese originalmente dirigida ao juiz, e não ao legislador.

Assim, para Alexy, se nem mesmo no discurso ideal é possível ter certeza que existe uma única resposta para toda questão jurídica, encontrar uma única resposta não deve ser possível também no discurso real, pelo menos em alguns casos. Por essa razão, para Alexy, a única resposta deve permanecer, para o juiz, como uma ideia regulativa.

\subsection{Discricionariedade legislativa na Teoria Discursiva do Direito de Alexy}

Alexy abordou a discricionariedade legislativa em conexão com sua teoria dos princípios. O primeiro esboço da teoria dos princípios de Alexy apareceu no ensaio Zum Begriff des Rechtsprinzips (Sobre o conceito de princípio jurídico), publicado em 1979, em Alemão, ${ }^{23}$ tendo sido desenvolvida posteriormente em sua Teoria dos Direitos Fundamentais, publicada inicialmente em Alemão, em 1985. ${ }^{24}$

Após isso, a teoria dos princípios de Alexy tornou-se internacionalmente renomada, recebeu tanto aprovação geral quanto críticas severas, na Alemanha e ao redor do mundo, foi objeto de vários desenvolvimentos, por parte do próprio Alexy e por outros autores, e exerceu grande influência na teoria do direito e na prática do direito ao redor do mundo. Significantes evoluções foram realizadas por Alexy no ensaio Die Gewichtsformel (A fórmula do peso), publicado originalmente em Alemão, em 1993, ${ }^{25}$ no Apêndice da edição em Inglês da Teoria dos Direitos Fundamentais ${ }^{26}$ e no recente ensaio Princípios Formais, publicado pela primeira vez em português, em junho de 2014, e então em Inglês, em Julho de $2014 .{ }^{27}$

\footnotetext{
${ }^{23}$ Cf. ALEXY, Robert, Zum Begriff des Rechtsprinzips, in: Rechtstheorie 1 (1979), 59-87; tradução em português: Sobre o Conceito de Princípio Jurídico, A. T. G. Trivisonno (trad.), in: Teoria Discursiva do Direito, A. T. G. Trivisonno (org.). Rio de Janeiro: Forense Universitária, 2014, 163-198.

${ }^{24}$ Cf. ALEXY, Robert, Theorie der Grundrechte, Baden-Baden: Nomos, 1985 (reimpressão Frankfurt a. M.: Suhrkamp, 1986 [usada nas citações deste ensaio]);

${ }^{25}$ ALEXY, Robert, Die Gewichtsformel, in: Gedächtnisschrift für Jürgen Sonnenschein, J. Jickeli, P. Kreutz and D. Reuter (orgs.), Berlin: De Gruyter, 2003, 771-792.

${ }^{26}$ ALEXY, Robert, A Theory of Constitutional Rights, J Rivers (trad.). Oxford: Oxford University Press, 2010, Postscript, 394 f; Teoria dos Direitos Fundamentais, Posfácio, 584.

${ }^{27}$ ALEXY, Robert, Princípios Formais, A. T. G. Trivisonno (trad.), in: Princípios Formais e Outros Aspectos da Teoria Discursiva do Direito, A. T. G. Trivisonno, A. T. Saliba e M. S. Lopes (org.), Rio de Janeiro 2014, 3-36.
} 
Já no Apêndice da Teoria dos Direitos Fundamentais, Alexy distingue discricionariedade legislativa estrutural e discricionariedade legislativa epistêmica. A discricionariedade legislativa estrutural compreende aquilo que as normas constitucionais não comandam nem proíbem, ${ }^{28}$ enquanto a discricionariedade legislativa epistêmica "surge sempre que o conhecimento sobre aquilo que é comandado, proibido ou deixado livre pelos direitos fundamentais é incerto". ${ }^{29}$

No ensaio Princípios Formais, Alexy reafirma essa distinção. O referido ensaio tem como objetivo discutir o papel que os princípios formais desempenham em relação à discricionariedade do legislador e, assim, no controle de constitucionalidade. Alexy desenvolve uma ideia que já havia aparecido no Apêndice da edição em Inglês da Teoria dos Direitos Fundamentais: a discricionariedade epistêmica está relacionada à certeza não só das suposições empíricas, mas também das suposições normativas referentes aos princípios colidentes. ${ }^{30} \mathrm{~A}$ fim de expressar isso, Alexy desenvolve uma nova versão da fórmula do peso, por ele denominada "fórmula do peso completa refinada", que inclui uma variável referente à certeza das suposições normativas.

Assim, após a nova versão da fórmula, a discricionariedade legislativa epistêmica decorre não somente do fato de o legislador não ter certeza, em alguns casos, sobre as suposições empíricas referentes à matéria em questão, mas também do fato de ele não ter certeza sobre as suposições normativas referentes a ela. Assim a nova fórmula possibilita diferenciar formalmente os casos nos quais o empate de uma colisão entre princípios decorre de incerteza das suposições empíricas (variável $R^{e}$ ) dos casos nos quais o empate decorre da incerteza das suposições normativas (variável $R^{n}$ ).

Em síntese, em Alexy, a discricionariedade legislativa possui uma natureza dupla: ela existe quando a constituição não regulamenta algo (discricionariedade estrutural) e quando o legislador não pode ter certeza sobre aquilo que a constituição determina (discricionariedade epistêmica).

\section{Princípio da Moralidade}

\footnotetext{
${ }^{28}$ ALEXY, A Theory of Constitutional Rights, Postscript, 394 s.

${ }^{29}$ ALEXY, A Theory of Constitutional Rights, Postscript, $414 \mathrm{~s}$.

${ }^{30}$ ALEXY, Princípios Formais, 30 ss.
} 
Analisados alguns aspectos essenciais da discricionariedade no direito passamos, como planejado, a investigar os contornos do princípio da moralidade no direito brasileiro.

O princípio da moralidade está expressamente previsto no art. 37 da Constituição Brasileira, constituindo o fundamento principal da súmula vinculante $\mathrm{n}^{\mathrm{o}} 13$, como ressalta Khouri na obra Súmula Vinculante $n^{\circ} 13$ e Moralidade Administrativa: estudo do Nepotismo à luz dos princípios constitucionais da Administração Pública e possível anomia legislativa. ${ }^{31}$

A fim de se compreender o sentido e o alcance do princípio da moralidade é necessário, primeiramente, analisar a distinção entre moral e direito. Segundo Trivisonno, o termo moral pode ser empregado em vários sentidos, dentre os quais dois se destacam, sobretudo na filosofia moral e na teoria do direito: moral positiva e moral ideal. Por um lado, a moral positiva é o conjunto de normas positivas diversas do direito, que têm como fonte, por exemplo, os costumes ou uma autoridade religiosa. Por outro lado, a moral ideal compreende a ordem moral que não é positivada sob nenhum aspecto, mas pressupõe um nível de concordância e consenso de todos. EXPLICAR MELHOR KELSEN

Segundo Trivisonno, a moral ideal possui maior objetividade que a moral positiva, pois não depende das características ou peculiaridades de determinado grupo social ou convenção costumeiramente estabelecida, tratando de elementos que são comuns a todos os seres humanos. Constitui exemplo de moral ideal a moral concebida por Immanuel Kant.

A moral positiva, por sua vez, compreende a ordem tangível estabelecida em regras ou costumes estatuídos, possuindo, assim, maior grau de subjetividade (que não se confunde com a textura aberta de conceitos indeterminados, por exemplo, mas compreende a ausência de consenso ou padrão), visto que é altamente variável de acordo com a sociedade e o tempo em que se manifesta. Kelsen concebe a moral como ordem positiva desprovida de coerção, e não como uma ordem ideal. ${ }^{32}$

\footnotetext{
${ }^{31}$ CF. KHOURI, Alice de Siqueira. Súmula Vinculante $n^{o} 13$ e Moralidade Administrativa: estudo do Nepotismo à luz dos princípios constitucionais da Administração Pública e possível anomia legislativa. Belo horizonte: PUC Minas, 2017.

32 Trivisonno explica melhor a distinção acima sintetizada: "Embora existam, na história da filosofia ocidental, diversas concepções sobre moral, duas tendências gerais parecem destacar-se. Para alguns autores, entende-se por moral um conjunto de normas positivas diverso do direito, que tem como fonte os costumes ou uma autoridade religiosa. Os defensores desse tipo de concepção geralmente atribuem um caráter relativo e subjetivo à moral. Exemplo dessa concepção constitui a Teoria Pura do Direito de Hans Kelsen. Por outro lado, para outros autores, entende-se por moral uma ordem que não é positiva, mas sim ideal, que retira sua validade de Deus, da natureza ou da razão, e que possui certa objetividade. Exemplo dessa concepção constitui a filosofia moral de Immanuel Kant. Autores que defendem a primeira concepção, ou seja, aquilo que se pode denominar ética empírica, rejeitam, de modo geral, tanto a existência de uma moral ideal quanto à ideia de que a moral é objetiva. Não é por outro motivo que Kelsen rejeita o imperativo categórico de Kant como princípio supremo da moralidade (cf. KELSEN, 2016). Por outro lado, autores que defendem a segunda concepção, ou seja, uma moral ideal, consideram que a
} 
Tal distinção possui grande relevância, sobretudo para a determinação da relação entre direito e moral: teóricos que defendem a tese da separação entre direito e moral geralmente concebem a moral como uma ordem positiva, enquanto aqueles que defendem a tese da conexão geralmente a concebem como uma ordem ideal.

É essencial determinar se e em que medida se pode atribuir ao direito uma relação necessária com a moral, bem como estabelecer uma distinção clara entre a mora e o princípio da moralidade, sendo este concebido com um conceito jurídico.

Para Kelsen (2006), o Direito e a Moral são espécies distintas de sistemas normativos, não sendo possível diferenciá-los através de um suposto caráter externo do direito e interno da moral, pois, em sua visão, tanto o direito quanto a moral são conjuntos de normas que regulamentam condutas humanas, limitando-as externa e internamente. ${ }^{33}$

Na visão Kelsen, tampouco é possível distinguir com excelência moral e direito a partir da produção ou aplicação de suas normas, pois ambos os sistemas têm normas criadas pelo costume ou por meio de uma elaboração consciente. Assim, Kelsen (2006) explica que a separação entre o direito e moral não se configura a partir daquilo que as duas ordens normativo-sociais prescrevem ou proíbem, mas sim como essas ordens prescrevem ou proíbem condutas. $^{34}$

Vê-se, portanto, que, em Kelsen (2006), a moral é concebida como ordem positiva sem caráter coercitivo, enquanto o direito, por outro lado, é considerado uma ordem coercitiva. ${ }^{35}$

moralidade positiva não constitui a verdadeira moral, exercendo, quando muito, um papel secundário. Parece claro que se a primeira concepção estiver correta, ou seja, se a moral for compreendida como moralidade positiva, não faz sentido defender a conexão entre direito e moral, pois aquilo que é justo para alguém não é necessariamente justo para outro, muito menos para todos.” (TRIVISONNO, 2015, p. 105-106, grifo nosso).

${ }^{33}$ Radbruch, em consonância com Kelsen no que diz respeito à questão da interioridade/exterioridade como critério distintivo entre direito e moral, e em divergência neste ponto com Kant, explica: "Não há, pode dizer-se, um único domínio da conduta humana, quer interior, quer exterior, que não seja suscetível de ser ao mesmo tempo objeto de apreciações morais e jurídicas. Todavia - note-se - aquilo que a princípio parece ser uma distinção entre a Moral e o Direito, pode manter-se ainda, mas como uma distinção entre duas direções opostas dos seus respectivos interesses. Isto é: a conduta exterior só interessa à Moral na medida em que exprime uma conduta interior, a conduta interior só interessa ao Direito na medida em que anuncia ou deixa esperar uma conduta exterior." (RADBRUCH, 1997, p. 99-100).

34 “'O Direito só pode ser distinguido essencialmente da moral quando - como já mostramos - se concebe como uma ordem de coação, isto é, como uma ordem normativa que procura obter uma determinada conduta humana ligando à conduta oposta um ato de coerção socialmente organizado, enquanto a moral é uma ordem social que não estatui quaisquer sanções desse tipo, visto que as suas sanções apenas consistem na aprovação da conduta conforme as normas e na desaprovação da conduta contrária às normas, nela não entrando sequer em linha de conta, portanto, o emprego da força física." (KELSEN, 2006, p. 71).

35 Trivisonno ressalta que o pensamento kantiano, apesar de estabelecer a coerção como uma característica que distingue a moral e o direito, não para aí, adicionando outros critérios, como o da exterioridade/interioridade: (...) o direito tem a ver somente com a forma na relação da escolha, não com a matéria da escolha. Consequentemente, não me comanda a agir por dever, mas me permite, antes, adotar qualquer finalidade desde que a ação exigida seja 
Estabelecida a distinção entre direito e moral, Kelsen passa então a analisar a relação entre esses dois sistemas. Sobre isso, Kelsen (2006) diferencia a relação que de fato existe e a relação que deveria existir entre moral e direito.

Sobre a relação que de fato existe entre moral e direito, Kelsen (2006) esclarece que o direito só poderia ser concebido como essencialmente moral se, por moral se entendesse uma unidade válida, ou seja, a existência de uma moral absoluta, objetiva, e não uma moral relativa ou subjetiva, que comportaria múltiplas concepções e, assim, não constituindo assim um sistema normativo coeso e harmônico, como o direito. Assim, para que normas morais sejam consideradas como integrantes do direito, essas normas têm de se referir a uma moral única, objetiva, e não relativa.

Quando porém se investiga a relação que deveria existir entre moral e direito, a partir da concepção de um conteúdo moral ou de um caráter moral do direito, no sentido de que o direito deve ter um conteúdo moral mínimo, deve prescrever algo que é moralmente aceito em uma perspectiva de dever-ser, mas que não necessariamente o fará.

Independentemente da relação que se admita entre moral e direito, o fato é que, para Kelsen, a separação entre os dois sistemas normativos pressupõe a independência da ordem jurídica positiva em relação à moral, o que não equivale dizer que direito e moral são totalmente alheios Kelsen (2006) ensina, portanto, que Direito e Moral são ordens normativas distintas entre si, principalmente, pelo caráter coercitivo do Direito, ausente no caso da Moral. Contudo, também esclarece o autor que esses sistemas normativos se relacionam entre si, como já dito, em formas que podem ser analisadas sob o viés do que efetivamente são e do que devem ser.

Kelsen esclarece que a validade do direito independe da moral, pois quando se analisa "moralmente" uma norma jurídica, deve-se ter em mente que essa análise pode variar, a depender do sistema moral que se tome como parâmetro.

Considerando existirem múltiplas concepções do que é moral, bem como o fato de essa variação não ser capaz de invalidar o sistema jurídico, sob pena de insegurança na ordem normativa do direito, Kelsen enfatiza que:

Devemos ter presente, porém, quando apreciamos 'moralmente' uma ordem jurídica positiva, quando a valoramos como boa ou má, justa ou injusta, que o

executada. (...) Ora, o conceito do direito estabelece que o direito é a legislação externa dotada de coerção e, uma vez que uma legislação externa pode obrigar apenas as ações a serem executadas, mas não a vontade a ser livre, o direito tem que a ver somente com ações e não com intenções. (TRIVISONNO, 2015, p. 193/194). 
critério é um critério relativo, que não fica excluída uma diferente valoração com base num outro sistema de moral, que, quando uma ordem jurídica é considerada injusta se apreciada com base no critério fornecido por um sistema moral, ela pode ser havida como justa se julgada pela medida ou critério fornecido por um outro sistema moral. (...) A tese, rejeitada pela Teoria Pura do Direito, mas muito espalhada na jurisprudência tradicional, de que o Direito, segundo a sua própria essência, deve ser moral, de que uma ordem social imoral não é direito, pressupõe, porém, uma moral absoluta, isto é, uma moral válida em todos os tempos e em toda parte. De outro modo não poderia ela alcançar o seu fim de impor a uma ordem social um critério de medida firme, independente de circunstâncias de tempo e de lugar, sobre o que é direito (justo) e o que é injusto. (KELSEN, 2006, p. 76-78).

Ora, se a moral não gera, por si só, a invalidade do direito, o que equivale dizer que se uma norma jurídica não é necessariamente inválida por não ser correspondente a uma determinada moral, não há que se falar em invocar determinado elemento da moral para justificar uma "norma" do direito ou lhe conferir pretensão de legitimidade. Existem várias razões para isso, dentre elas o fato de a moral não se encontrar em um plano axiológico objetivo como o Direito, sendo, ao contrário, altamente subjetiva e comportando prismas variáveis que não conferem ao direito a segurança que lhe é necessária. É por essa razão que não se pode recorrer à moral para conferir validade a uma determinada norma jurídica.

Essas considerações de Kelsen valem, em nosso entendimento, para o princípio da moralidade. Como ressalta Cammarosano:

Num Estado democrático, o princípio da moralidade, conquanto de conteúdo rarefeito, só poderia estar reportado à moral comum, sem ofensa aos valores supremos da liberdade, certeza e segurança jurídica que a ordem constitucional prioriza, se se pudesse afirmar a existência de uma só moral, absoluta, objetivamente identificável. (CAMMAROSANO, 2006, p. 43).

Uma vez que o principal fundamento da súmula 13 é o princípio da moralidade, compreender o significado de moral, bem como sua distinção e relação com o direito, é, portanto, essencial para a compreensão de sua justificação, pois a norma constitucional supostamente violada pelo ato de nepotismo, utilizada de forma genérica e pouco argumentativa para sustentar o caráter discricionário da decisão tomada não pode ser outra que não a moralidade administrativa, conceito jurídico que será analisado posteriormente. 
Delineada a distinção teórica entre direito e moral, ressalta-se que a relação entre ambos se dá mediante uma clara separação dos elementos de cada ordem normativa, pois não há como confundir as duas ordens em um estado que se proclame democrático, pelas razões de segurança e objetividade. Mais do que diferentes, a moral não pode ser invocada como forma de invalidar o direito quando existentes elementos do direito positivo vigentes, claros e consistentes, sob pena de se estar assumindo entre os dois uma relação de hierarquia e subsunção em detrimento à segurança jurídica.

Isso não quer dizer que moral e direito não tenham relação. Como vimos acima, o discurso jurídico é, para Alexy, um caso especial do discurso prático geral. Isso significa, em nosso entendimento, que há entre o discurso prático geral e o discurso do sistema jurídico, uma simbiose:

\begin{abstract}
Discursos práticos gerais são diferentes de discursos jurídicos por não dependerem de razões institucionais. Para a argumentação jurídica, razões institucionais como a lei e o precedente são constitutivas, para a argumentação prática geral eles não são. (...) $\mathrm{O}$ discurso prático geral é, em suma, um discurso que combina os pontos de vista da conveniência ou utilidade, do valor ou identidade e da moralidade ou justiça. Essa combinação não constitui porém uma mera adição. Existe tanto uma ordem de precedência quanto uma relação de permeação entre o conveniente, o bom e o justo. (ALEXY, 2015b, p. 97-98).
\end{abstract}

$\mathrm{Na}$ opinião do autor, o discurso prático geral assume peculiar importância quando o sistema jurídico se mostra insuficiente na solução de conflitos ou mesmo na argumentação em geral e, em contrapartida, a fundamental importância do discurso jurídico reside no alívio em que ele proporciona da carga moral tão predominante no discurso prático.

Para Alexy (2015b), o discurso prático geral não se confunde com o discurso moral no sentido de Habermas da 'razão moral' mas compreende, em verdade, a coexistência das razões ética, pragmática e moral.

O discurso jurídico, como caso especial do discurso prático geral, admite a importação de razões deste último discurso, quando omisso o direito positivo vigente (dogmática jurídica [ou doutrina], lei e precedentes [ou jurisprudência]). Porém, na visão de Alexy, o discurso prático geral, sobretudo o discurso moral, pode invalidar uma norma jurídica vigente em caso de injustiça extrema ${ }^{36}$. Assim, para Alexy (2015b), quando da solução de uma questão jurídica,

\footnotetext{
${ }^{36}$ Trivisonno menciona o conceito formulado por Radbruch de injustiça e esclarece a visão de Alexy quanto a este conceito: "No ensaio injustiça legal e direito supra-positivo, publicado em 1946, Radbruch apresenta a formulação clássica do argumento da injustiça: ' $O$ conflito entre a justiça e a segurança jurídica pode ser resolvido de modo que o direito positivo, assegurado através de um estatuto e do poder, tem então a precedência, mesmo quando seu conteúdo for injusto e inconveniente, a não ser que a contradição da lei positiva em relação à justiça atinja uma medida tão intolerável que a lei, enquanto 'direito injusto', tem que ceder à justiça.' (RADBRUCH, 1990b, p.
} 
o retorno ao discurso prático geral só pode ocorrer quando o direito positivo vigente for omisso ou quando o direito positivo for extremamente injusto (em suma, violação gravíssima à moral ideal e não à moral positiva).

Em outras palavras, o direito válido é essencial para a solução de problemas práticos, pois na medida em que possui comandos racionais para a solução de problemas, oferecendo parâmetros objetivos, ${ }^{37}$ pode remediar a abstração da moral, conduzindo assim a resultados mais eficazes e consistentes do que aqueles proporcionados por mera justificativa moral ou por apelo a valores não institucionalizados.

Ao admitir a existência de uma relação bidirecional entre o discurso prático geral e o discurso jurídico, Alexy (2015b) nos fornece um ponto de vista teórico que justifica a utilidade do direito positivo válido traz à tona seu aspecto de essencialidade para a consistência das decisões jurídicas, bem como para a contenção de uma discricionariedade jurídica desgovernada.

A tendência de desprezo à positividade do direito, por vezes confundida como o positivismo jurídico, sobretudo o positivismo legalista, ${ }^{38}$ mostra-se incoerente com a teoria do discurso de Alexy (2015b), como se nota na passagem transcrita abaixo:

\footnotetext{
345). Alexy afirma que tal passagem citada pode ser lida de várias formas, e então constrói sua versão do argumento da injustiça, afirmando que normas isoladas de um sistema jurídico perdem, quando ultrapassam determinado limiar de incorreção ou de injustiça, seu caráter jurídico (ALEXY, 1992b, p. 88; 2014d, p. 275). Mas qual deve ser esse limiar? Alexy recorda que Radbruch usa os termos 'intolerável' (unerträglich) e 'horrenda' (horrend). Contudo, para ele, o termo 'extrema' parece mais adequado, pois expressa a ideia de um limite localizado na terminação superior de uma escala (ALEXY, 2008, p. 282). Para ele, 'a versão mais curta que se pode conceber da fórmula de Radbruch rezaria então: a injustiça extrema não é direito.' (ALEXY, 2008, p. 282, grifo nosso; cf. também ALEXY, 2010, p. 175, 2014b, p. 313). Antes de investigar a relação entre o argumento da injustiça e o conceito de direito de Alexy cumpre averiguar em que medida o argumento da injustiça afeta, na visão de Alexy, a validade não apenas de normas jurídicas isoladas, mas também de ordens jurídicas globalmente consideradas. Alexy afirma que o argumento da injustiça, de Radbruch, constitui uma tese que se refere a normas jurídicas isoladas, e não a ordens jurídicas globalmente consideradas (ALEXY, 1992b, p. 88; 2014d, p. 275). No Livro Conceito e Validade do Direito, publicado em 1992, ele analisa em que medida uma ordem jurídica que contém normas (extremamente) injustas perde sua validade como um todo. Alexy aborda duas possíveis teses, a tese da extensão e a tese do colapso (ALEXY, 1992a, p. 110).” (TRIVISONNO, 2015, p. 99).

${ }^{37} \mathrm{Em}$ virtude de suas vinculações, a insegurança de resultados do discurso jurídico é consideravelmente menor que a do discurso prático geral. (ALEXY, 2015b, p. 89).

${ }^{38} \mathrm{O}$ positivismo é conhecido pela marca da objetividade e separação conceitual entre Direito e moral à medida que o Direito é tido como o conjunto de normas institucionalmente validadas. Nesse sentido, Hudson Couto Ferreira de Freitas (2013) enumera didaticamente: "O que importa é que todas estas teses jurídicas já traziam embrionariamente os principais elementos do positivismo jurídico, que foram firmados ao longo dos séculos XIX e XX, em especial: a) sobre a fonte primordial do Direito passar a ser o Estado; b) sua descrição, interpretação e aplicação somente poderiam ser feitas de forma racional e científica por meio de métodos de interpretação; c) considerar o Direito como uma ciência autônoma e auto-referencial; d) e, via de consequência, adotar a tese da separação entre o Direito e a Moral, de modo que o Direito seja concebido como um sistema fechado e autônomo, admitindo, no máximo, uma interpenetração acidental e contingente entre tais ordens, como só ocorre entre os positivistas denominados inclusivistas." (FREITAS, 2013, p. 49). Com a evolução do Direito e o advento de teorias que se dedicaram a repensar o Direito, começaram a surgir as teses anti-positivistas e pós-positivistas, que criticam
} 
O discurso jurídico se distingue do discurso prático geral através de seus vínculos. Nele não se pergunta qual é a solução absolutamente mais racional, mas qual é a solução mais racional no sistema jurídico. (...) Esses três fatores vinculantes, a lei, os precedentes e a dogmática, na verdade estipulam muito, mas também deixam muitas coisas em aberto, o que constitui uma das várias explicações para o enorme número de questões jurídicas polêmicas. Nesses casos, trata-se sempre, no final das contas, daquilo que é comandado, proibido ou permitido, ou seja, de questões práticas. Quando não se pode encontrar uma resposta para essas questões somente com a ajuda do instrumentário especificamente jurídico, resta somente o retorno ao discurso prático geral. Isto significa, porém, que o procedimento do discurso jurídico, se em seu caso de deve tratar de soluções racionais, deve ser definido através de dois sistemas de regras: por um lado através de regras específicas do discurso jurídico, que expressem a vinculação com a lei, com os precedentes e com a dogmática, e, por outro lado, através das regras do discurso prático que levem em consideração a pretensão de que os julgamentos jurídicos sejam fundamentáveis racionalmente no contexto do ordenamento jurídico. Isso constitui uma razão a favor da tese de que o discurso jurídico é o caso especial do discurso prático geral, caracterizado por algumas vinculações. (ALEXY, 2015b, p. 88).

A partir da tese do caso especial de Alexy (2015b) e da interação entre discurso prático geral (que sedia a moral) e discurso jurídico (representação do direito válido), é possível evidenciar a (des)conexão entre a argumentação desenvolvida pelo STF para justificar a súmula vinculante 13 e o discurso jurídico, na medida em que o STF não buscou uma solução para a

a objetividade marca do positivismo reduzindo-a a um simplismo que não condiz com a complexidade da linguagem jurídica. Quanto a tais críticas, Hudson Couto Ferreira de Freitas (2013) esclarece: “(...) o constructo positivista, da mesma forma que o jusnaturalismo, pressupõe a existência de um mundo objetivo, composto por objetos que possuem existência em si mesmos, apartados, portanto, do próprio ser humano. Daí a crença na existência de valores objetivos e, portanto, no nível das normas jurídicas, dos significados unívocos, uma vez que a linguagem utilizada para compor as normas designariam objetos que possuiriam essências próprias as quais conduziriam a significados precisos e cerrados. (...) Diante disso, as teses anti e pós-positivistas acusam o modelo positivista de irracionalidade, uma vez que em qualquer de suas vertentes permanece o pressuposto de que haveria conceitos (jurídicos) unívocos a serem verificados nas normas jurídicas, seja no texto da lei, ou na jurisprudência ou, mesmo, na ideia de costumes reconhecidos como normas jurídicas por uma autoridade (o juiz, por ex.)" (FREITAS, 2013, p. 116).

Ademais, o cenário de desprezo ao positivismo também foi muito influenciado pela percepção de que este sistema legitimara as atrocidades cometidas no período nazista alemão. Assim, grande parte das críticas ao positivismo foi endossada com o argumento de que a lógica positivista, por supor uma ausência de carga moral na norma jurídica, autorizava referidas atrocidades e uma completa desconexão com certos conceitos considerados axiológicos, como justiça. Cynthia Pereira de Araujo (2015) esclarece, inclusive, o equívoco de tal suposição: "A afirmação descontextualizada de que, para o positivista, nao há conexão conceitualmente necessária entre Direito e Moral, entre o que a lei determina e o que a justiça requer, pode levar ao equivocado entendimento de que o Positivismo Jurídico é indiferente à necessidade de busca pela justiça e que, por isso, acabou propiciando a ocorrência do nazismo. Conforme esclarecem os positivistas, destacando-se, neste ponto, Kelsen (2001) e Hart (2009), a tese de desvinculação entre o Direito e Mora deve-se à impossibilidade de se decidir de forma objetiva 'qual' justiça consagrar, o que, de forma indireta, implica exatamente evitar injustiça. Essa é apenas uma das razões pelas quais a imparcialidade buscada no Direito pelo Positivismo Jurídico não equivale a buscar um Direito sem valor, mesmo porque, consoante reconhece Recaséns Siches (1970, p. 380), toda norma jurídica é fruto de uma escolha, de uma preferência, e essa sempre exige uma valoração prévia. Ademais, ainda que se pudesse falar em suposta indiferença a valores por parte do Positivismo Jurídico, isso não equivaleria à má-valoração operada por um regime totalitário." (ARAÚJO, 2015, p. 135). 
questão do nepotismo através de uma argumentação racional, ${ }^{39}$ que considera não só o discurso prático geral, mas também o direito válido.

A justificativa do Tribunal Constitucional brasileiro invocou a moral comum, sob a denominação "princípio da moralidade", na medida em que ignorou os parâmetros do direito existentes, inerentes ao próprio conceito da norma jurídica de moralidade administrativa. A invocação da moral, nesse caso, conduz à descaracterização do discurso jurídico, privilegiando assim o discurso prático geral, pois ignora os elementos do discurso jurídico válido (regra do artigo constitucional $n^{\circ} 37$, II, e a obrigatoriedade de a matéria ser objeto de restrição por lei).

A teoria de Alexy (2015b) nos conduz a algumas reflexões que podem ser úteis para a solução da questão do nepotismo: comporta a sociedade uma extinção do discurso jurídico e um desapego ao direito positivo? O império do discurso prático geral e seus argumentos em detrimento das diretrizes normativas existentes no direito válido não nos conduziria a uma subjetividade muito grande e eventualmente ao arbítrio do julgador? A invocação da moralidade como referência à moral não seria uma violação à própria legalidade e à moralidade enquanto normas jurídicas, representando a assunção de uma discricionariedade desmedida e tendente ao arbítrio judicial?

Para responder a essas questões faz-se necessário definir o que é moralidade administrativa e qual a medida mais eficaz na concretização dessa norma constitucional, questões para as quais o direito válido parece ter bastante contribuição a fornecer, sem necessidade de recorrer ao discurso prático geral.

Há autores que discordam da necessidade de distinção entre moral e direito apresentada e defenda um conceito de moralidade jurídica atrelado a elementos não jurídicos, mas integrantes da moral (ou do discurso prático geral no sentido de Alexy [2015b]). Exemplo do grupo de juristas que defendem um conceito de moralidade enquanto princípio jurídico atrelado à moral e não propriamente ao direito constitui a Ministra (atualmente Presidente) do STF Carmen Lúcia Antunes Rocha (1994), que repudia o distanciamento entre moral e direito ${ }^{40}$.

\footnotetext{
${ }^{39} \mathrm{Na}$ teoria de Alexy (2015b, p. 88), o foco não é a discussão acerca da racionalidade das decisões, mas o autor faz questão de esclarecer que: "Eu gostaria de renunciar aqui a analisar mais de perto o conceito de solução mais racional no sistema jurídico e simplesmente dizer que ela é aquela que pode ser fundamentada da melhor maneira possível considerando-se o vínculo com as normas jurídicas válidas, os precedentes e a dogmática elaborada pela ciência do direito."

${ }^{40}$ Nas palavras de Rocha, "o sentido contemporâneo da Democracia, o seu primado absoluto em todo o mundo, como objetivo a ser buscado, fez com que a Ética passasse a comungar com os padrões políticos a serem adotados e a Moral, a integrar o Direito, tornando-se jurídicas normas anteriormente sediadas apenas no campo da moral. (...). Parece que a colocação Direito versus Moral é apenas uma falsa equação, que não se sustenta sob o influxo do princípio democrático.” (ROCHA, 1994, p. 180).
} 
Partindo da necessidade de aproximação e estreitamento dos laços entre direito e moral, Rocha (1994, p.187-194) define a moralidade como princípio derivado da legalidade, cuja força normativa foi estatuída pela Constituição da República de 1988, mas que desde sempre integrou o rol de requisitos para a atividade administrativa e dentro da lei.Na visão da autora, o conceito de moralidade administrativa possui elementos ligados mais à moral que ao direito, na medida em que invoca valores axiológicos subjetivos como 'bom', ‘justo' e 'honesto':

\begin{abstract}
O fortalecimento da moralidade administrativa como princípio jurídico deu-se, pois, com a aceitação da idéia de que o serviço público tem que atender ao que é justo e honesto para a sociedade a que se destina. A Administração Pública tem, pois, que tomar a si a responsabilidade de realizar os fins da sociedade segundo padrões normativos de justiça e justeza, esta configurada pelo conjunto de valores éticos que revelam a moralidade. (ROCHA, 1994, p. 191).
\end{abstract}

Reforça a autora, contudo, que apesar da presença de elementos típicos da moral, a força normativa do princípio da moralidade administrativa repousa no fato de ele ser estatuído pelo direito positivo em sua lei maior, a Constituição da República, representando, portanto, a vontade do povo e um valor democrático inafastável ${ }^{41}$.

Concordamos com Rocha no que diz respeito à força normativa e ao caráter principiológico da moralidade administrativa. Nossa dissonância com seu pensamento reside na invocação de elementos da moral para conceituar o referido princípio, que, por ser jurídico e positivo, deve em seu conceito guardar relação com o direito positivo válido e não necessariamente com a moral.

É sabido que a ordem democrática pressupõe segurança nas relações jurídicas, o que só é alcançado mediante normas jurídicas estáveis, claras e objetivas. Para que sejam estáveis, claras e objetivas, as normas jurídicas não podem ser impregnadas de conceitos variáveis e filosoficamente subjetivos, como é a moral, pois ela pode ser compreendida, como vimos, de diversas maneiras. Por essa razão, compreender o princípio da moralidade como um comando que determina a efetivação da moral atenta à segurança necessária em um estado democrático, pois a importação de valores e argumentos de outra ciência ou conjunto normativo alheio ao direito (discurso prático geral de Alexy), cuja abstração e consequentemente indeterminação

\footnotetext{
${ }^{41}$ A moralidade administrativa legitima o comportamento da Administração Pública, elaborada como ela é por um Direito nascido do próprio povo. Por isso, é o acatamento da moralidade administrativa, como princípio de Direito que dota o sistema de legitimidade, o que se estende à qualificação legítima do Poder do Estado. (ROCHA, 1994, p. 191).
} 
são inegavelmente muito altas, dificulta o controle juridicamente válido proporcionado pelo direito positivo válido (discurso jurídico) e implica uma discricionariedade judicial desgovernada.

O elemento ético, que reflete os valores de justiça e honestidade da sociedade, integra o conceito de moralidade administrativa, que portanto não é alheio às exigências da sociedade e seus padrões de probidade. Porém, mais do que eles, é necessária a vinculação a elementos do direito positivo válido, para que a moralidade não seja um princípio dissociado da legalidade, sendo usada como justificativa para uma discricionariedade que viola o direito.

O princípio da moralidade administrativa advém da própria legalidade constitucionalmente estabelecida, exigindo porém outros aspectos que transcendem a legalidade estrita, mas que dela decorrem.

Segundo Manoel Franco Sobrinho (1993) o mínimo ético do direito reside na expectativa de um "direito justo". Ainda que por justiça se entenda conceito de difícil parametrização e relevante carga subjetiva, o sistema jurídico deve compreender um consenso de justiça que repousa na unanimidade do conceito, na noção de equidade e de solidariedade, que geram o bem comum. Com base na defesa de um mínimo ético e da conexão necessária entre direito e moral, entendendo ser essencial à legalidade o controle da moralidade, Sobrinho define seu conceito de princípio da moralidade administrativa da seguinte maneira:

\footnotetext{
A tese da moralidade administrativa, portanto, sustenta-se no elemento moral que deve integrar forçosamente o ato administrativo. A moralidade aliada da eficácia, da conveniência e da equidade. Aparecendo, a moral, como elemento de mérito, de juízo, contra o erro, o dolo, a violência e a arbitrariedade. (SOBRINHO, 1993, p. 69).
}

No rol de dos administrativistas que se debruçaram sobre o conceito de moralidade administrativa enquanto princípio constitucional de observância obrigatória instituída pela Constituição da República de 1988 está Lúcia Valle Figueiredo (2008). Ela concebe a moralidade administrativa como dever do administrador e direito subjetivo público, vinculando-a ao direito válido:

No Vocabulaire Téchnique et Critique de André Lalande temos como morale, logo na acepção A: 'Conjunto de regras de conduta admitidas em dada época ou por um grupo de homens.' (tradução nossa). Dessa singela conceituação podemos, transpondo-a para o mundo jurídico, dizer que o princípio da moralidade vai corresponder ao conjunto de regras de conduta da Administração que, em determinado ordenamento jurídico, são consideradas os standards comportamentais que a sociedade deseja e espera. (FIGUEIREDO, 2008, p. 57). 
Assim, segundo Figueiredo (2008), há uma correlação necessária entre moralidade administrativa e legalidade, uma vez que desta deriva a própria moralidade, o que se evidencia a partir de sua definição como "conjunto de regras" que são standards "em determinado ordenamento jurídico".

Há que se ter evitar um conceito de princípio da moralidade administrativa que atrai a possibilidade de subjetivismo, por ser pouco democrático e pender à discricionariedade ilimitada, ou seja, à arbitrariedade.

A moral é uma ordem cujos comandos não possuem o mesmo rigor de validade que o direito. Exatamente por isso, a moral apresenta grande variação espaço-temporal. Sendo assim, é melhor que se tome como partida, para a solução de questões jurídicas, um conceito de moralidade administrativa mais próximo da legalidade, composto de exigências normativas essencialmente jurídicas, que conferem maior segurança não só ao próprio conceito, como também às suas implicações.

Nesse ponto vale transcrever, uma vez mais, o conceito de moralidade administrativa apresentado por Márcio Cammarosano:

\begin{abstract}
A moralidade administrativa tem conteúdo jurídico porque compreende valores juridicizados, e tem sentido a expressão moralidade porque os valores juridicizados foram recolhidos de outra ordem normativa de comportamento humano: a ordem moral. Os aspectos jurídicos e morais se fundem, resultando na moralidade jurídica, que é moralidade administrativa quando reportada à Administração Pública. $\mathrm{O}$ princípio da moralidade administrativa está referido, assim, não diretamente à ordem moral do comportamento humano, mas a outros princípios e normas que, por sua vez, juridicizam valores morais. É por essa razão que o princípio da moralidade administrativa não agrega ao mundo do Direito, por si só, qualquer norma moral que, se violada, implicaria invalidade do ato. Não há que se falar em ofensa à moralidade administrativa se ofensa não houver ao Direito. Mas só se pode falar em ofensa à moralidade administrativa se a ofensa ao Direito caracterizar também ofensa ao preceito moral por ele juridicizado, e não é o princípio da moralidade que, de per si, juridiciza preceitos morais. Portanto, violar a moralidade administrativa é violar o Direito. É questão de legalidade. A só violação de preceito moral, não juridicizado, não implica invalidade do ato. A só ofensa a preceito que não consagra, explicita ou implicitamente, valores morais, implica invalidade do ato, mas não imoralidade administrativa. (CAMMAROSANO, 2006, p. 113-114).
\end{abstract}

O conceito de moralidade administrativa, à luz do que propõe a Constituição da República de 1988, não pode dela dissociar-se: seja por se tratar da lei maior do ordenamento jurídico vigente, seja por dela própria derivar-se. E, na Constituição da República de 1988, a moralidade administrativa, prevista no art. 37 como princípio da Administração Pública, é, antes de tudo, uma norma jurídica. 
Enquanto norma jurídica, ela pertence ao direito e a esse sistema normativo se vincula. Apesar de seu conceito ser derivado do próprio princípio da legalidade, o princípio da moralidade administrativa autoriza a importação de conceitos da moral. Porém, uma vez juridicizados, ou seja, incorporados ao direito, tais conceitos não podem ser subjetivos e parciais. Eles não se conectam mais à moral positiva. Em outros termos, o princípio da moralidade administrativa revela uma conexão genética entre direito e moral, mas não uma conexão conceitual. Isso não significa negar sua textura aberta que, por vezes, parece remeter a um conceito jurídico indeterminado e comportar certa discricionariedade judicial quando de sua aplicação. Porém, não se pode ignorar a presença de elementos jurídicos que possibilitam a sua definição em casos concretos e imprimem segurança jurídica nas situações em que ele a moralidade administrativa é invocada.

\section{Conclusão}

A moralidade administrativa foi concebida, no ordenamento jurídico brasileiro, na forma de princípio jurídico. A tarefa de aplicação dos princípios deve ser realizada da maneira mais racional e consistente possível ${ }^{42}$, especialmente em casos como o princípio da moralidade administrativa, cuja aplicação pode ter por consequência o afastamento de regra constitucional já existente (tal como a contida no art. 37, inciso II, da CR/88).

Como vimos, tanto em Kelsen quanto em Hart o poder discricionário não significa que a decisão possa ser arbitrária, pois a indeterminação é sempre relativa e o juiz deve apresentar razões para a decisão.

A SV 13 constitui, em nosso entendimento, exemplo de discricionariedade judicial perniciosa, pois sua fundamentação, conforme a justificativa dos ministros quando da sua edição, foi baseada simplesmente na a observância obrigatória da 'moralidade', contida no caput do art. 37, da CR/88. Em outros termos, a observância da moralidade no serviço público justificaria, por si só, a proibição da conduta do nepotismo ${ }^{43}$.

\footnotetext{
${ }^{42}$ Alexy, quando discorre sobre a teoria da única resposta correta de Dowrkin e as múltiplas teorias sobre o papel dos princípios na procura e justificação dessa resposta correta, esclarece que: "A mais sólida teoria seria aquela que contém princípios e atribuições de pesos a princípios que melhor justifiquem as prescrições da constituição, as normas estabelecidas e os precedentes." (ALEXY, 2015b, p. 166).

${ }^{43}$ Nas palavras do ministro Menezes Direito: “Tenho a impressão de que estamos aprovando uma súmula que, do ponto de vista constitucional, é uma tese. Qual é a tese do ponto de vista constitucional? É dizer que o nepotismo está dentro da cabeça do artigo 37, ou seja, dentro do princípio da moralidade, e que ele independe de lei formal, ele decorre diretamente da Constituição". (BRASIL, 2008a, p. 20).
} 
Contudo, esse apelo à moralidade parece significar, na verdade, um retorno àquilo que Alexy denomina discurso prático geral, ou seja, a um discurso em que preponderam razões morais, éticas e pragmáticas (no sentido de Habermas), e não razões jurídicas, que se caracterizam pelo vínculo ao direito válido.

Por essa razão, entendemos que o correto conceito de moralidade administrativa propriamente dito, concebido pelo direito, não é o utilizado para a edição da SV 13. Em nosso entendimento, a conduta de livre nomeação de cargos comissionados, ainda que de parentes, não viola da moralidade administrativa, pois esse princípio deriva-se de uma legalidade estrita. Uma vez que a lei maior garante a liberdade de nomeação para cargos comissionados, reservando somente à lei a competência para limitá-la, parece-nos que considerar proibida a prática da indicação de parentes a esses cargos, por violar a moralidade administrativa, revela uma concepção de moralidade ligada à moral comum, o que gera uma discricionariedade judicial exacerbada.

Pretendeu-se desnudar, no presente artigo, através do exemplo da SV 13, o perigo na invocação distorcida de determinados princípios, que por serem em sua essência mais genéricos que as regras, são utilizados como justificativa para a discricionariedade judicial arbitrária. Contudo, uma importante constatação deve ser feita: viu-se que a moralidade consistente no argumento utilizado para edição da súmula não advém do direito e, portanto, não se confunde com o real princípio da moralidade. O princípio da moralidade administrativa, enquanto norma jurídica, dada as suas especificidades ressaltadas ao longo deste, jamais poderia ser justificativa para a discricionariedade desmedida ${ }^{44}$.

O viés democrático, que atrai a segurança jurídica como princípio fundamental do ordenamento jurídico e, para tanto, valoriza a legalidade não como um mero valor herdado do

\footnotetext{
${ }^{44} \mathrm{~A}$ incursão de aspectos essencialmente da moral comum e não diretamente do direito proporciona ao conceito um tom de subjetivismo, vaguidão e, portanto, espaço de possíveis arbitrariedades. Não é outro o conceito de moralidade administrativa se não o derivado da própria legalidade, norte de toda e qualquer atuação administrativa, seja nos seus elementos formadores, seja quanto aos seus efeitos.

Nesse ponto, parecem precisas e cristalinas, as lições de Márcio Cammarosano:

"A moralidade administrativa não pode ser dissociada da legalidade; pelo menos da legalidade em sentido amplo, entendida esta como a qualidade do que está conforme ou compatível com a ordem jurídica, e não apenas com a lei em sentido estrito. Na fórmula non omne quod licet honestum est - nem tudo que é lícito, é honesto, isto é, nem tudo que a lei permite é moralmente aceitável - o Direito e a Moral podem ser representados por dois círculos concêntricos, sendo maior o da Moral. A moralidade administrativa, contudo, não constitui esse círculo maior que extrapola o mundo jurídico, não expande o Direito de sorte a torna-lo compreensivo também do que estava em princípio fora dele, para além dele. A moralidade administrativa integra o Direito. Nem todo ato ilegal é imoral. Mas não se pode reconhecer como ofensivo à moralidade administrativa ato que não seja ilegal." (CAMMAROSANO, 2006, p. 102).
} 
positivismo, mas como forma de concepção dessa segurança jurídica, parece apoiar um conceito moderno de moralidade administrativa, tal como apresentado por Cammarosano (2006).

Não pretendemos condenar toda e qualquer discricionariedade judicial, o que engessaria a atividade interpretativa do julgador. Em relação à discricionariedade, parece-nos correta a posição de Alexy, exposta no item 2 acima, segundo a qual a discricionariedade legislativa é mais abrangente que a discricionariedade judicial. Como vimos, para Alexy, embora no âmbito da discricionariedade judicial se admita a ideia de uma única resposta correta, essa ideia se expressa como uma ideia regulativa, pois se nem mesmo no discurso ideal é possível ter certeza que existe uma única resposta para toda questão jurídica, encontrar uma única resposta não deve ser possível também no discurso real, pelo menos em alguns casos. Em nosso entendimento, no caso da SV 13 está-se diante de uma discricionariedade perniciosa, violadora da ordem democrática. Isso porque não houve uma demonstração satisfatória de que a conduta do nepotismo, em caso de indicação para provimento dos cargos em comissão e de confiança, viola a moralidade administrativa enquanto princípio jurídico. Não há tampouco como classificar o nepotismo como extrema injustiça (caso em que haveria mitigação do discurso jurídico através da importação de uma razão moral ideal), uma vez que não há violação gravíssima à ordem moral ideal.

Por meio das lições de Alexy, procuramos demonstrar que a discricionariedade legislativa existe quando a constituição não regulamenta algo (discricionariedade estrutural) e quando o legislador não pode ter certeza sobre aquilo que a constituição determina (discricionariedade epistêmica). Entendemos que as limitações às indicações de cargos de livre nomeação e exoneração estão no âmbito da discricionariedade legislativa, pois a liberdade de indicação dos cargos comissionados foi expressamente prevista pelo legislador constituinte, podendo ser restringida por lei. Essa previsão constitucional expressa, ou seja, uma previsão do direito válido, restringe a margem de manobra do julgador, ou seja, retira o tema do âmbito da discricionariedade judicial.

Do ponto de vista moral, sobretudo de uma moral positiva, o nepotismo tem como consequência uma repreensão, uma sanção social difusa, oriunda dos costumes e valores históricos. Como ressaltamos, o direito não possui uma conexão com a moral positiva, em virtude de sua alta carga de subjetividade. 
Defensores da ideia de que o nepotismo constitui violação genérica à moralidade poderiam afirmar que, o nepotismo viola não só a moral positiva, mas também a moral ideal, pois ele significaria a primazia da afinidade e do interesse privado em detrimento do interesse público, ou seja, na prática de nepotismo não prevaleceria a escolha do mais competente para o cargo, o que seria vedado não só plea moral positiva, mas também pela moral ideal. Contudo, se no caso do nepotismo o "problema moral" for a escolha por afinidade ou proximidade da autoridade nomeante com o servidor nomeado para o cargo de confiança, o nepotismo não poderia ser a única prática repreensível. Assim, dizer que a indicação de parentes viola a moralidade, pois há, nesses casos, o privilégio do interesse privado, implicaria invalidar a própria existência dos cargos comissionados, haja vista que todos esses cargos são preenchidos mediante escolhas que refletem afinidade ou proximidade entre a autoridade nomeante e o nomeado, até mesmo por questões de confiança inerentes àquele cargo em questão. Por essa razão, vê-se que é incoerente o argumento de que o nepotismo, por si só, violaria a moral ideal.

Não ignoramos os limites à liberdade de nomeação dos cargos de confiança. $\mathrm{Na}$ verdade, esses limites estão delineados pelos próprios princípios enunciados pelo caput do art. 37, da CR/88, dentre eles, o da moralidade e o da impessoalidade, de observância obrigatória e inafastável. Porém, o conceito desses princípios não pode se referir à moral comum ou ao discurso prático geral, pois eles, como normas jurídicas, não se confundem com a moral e dela não dependem para ter validade.

Portanto, a invocação do princípio da moralidade (elemento do direito) não pode se transformar em um argumento típico do discurso prático geral ou da moral positiva, devendo tal princípio guardar vinculação com o sistema jurídico ${ }^{45}$ no qual está inserido. Em síntese, a

\footnotetext{
${ }^{45}$ Nesse ponto, importante destacar que princípios, como a moralidade, razoabilidade e proporcionalidade representam conceitos jurídicos de difícil delimitação ou tangibilidade, possuindo certa fluidez que tende a comportar significados não jurídicos ou suportar a importação de elementos alheios ao direito positivo. Contudo, a dificuldade na determinação de tais conceitos, devido ao seu grau de abstração, mais acentuado no caso das normas tipo princípio, há de ser encarada com cautela pelos juristas quando da sua aplicação, para que não sejam desprezados elementos da ordem jurídica positiva quando da hercúlea tarefa de defini-los ou limita-los. Nesse sentido, pontua Cammarosano (2006), valendo-se das lições de Augustin Gordillo: "Vê-se, portanto, que não há como pretender, em rigor, que o princípio jurídico da moralidade administrativa esteja reportado direta e imediatamente a esta ou aquela ordem moral, cujos preceitos reputar-se-iam automaticamente juridicizados, e a nível constitucional. Está reportado, sim, a valores albergados no sistema jurídico, e cuja intelecção e aplicação não se pode dar fora desse mesmo sistema, ainda que permeável, pela própria fluidez dos conceitos normativos, às concepções significativas prevalecentes em dada sociedade e em dado momento histórico. Essa permeabilidade de certos conceitos, como os conceitos linhas atrás mencionados, faz-nos lembrar de lições de Austin Gordillo a respeito da existência, especialmente no Direito Público, de muitas palavras que 'constituem uma verdadeira estrutura oca', cuja função histórica tem sido tanto 'a de servir ao poder contra a liberdade' como 'de servir de enlace às valorações metajurídicas', permitindo 'introduzir variáveis axiológicas que significassem uma adequação permanente das normas à cambiante realidade."' (CAMMAROSANO, 2006, p. 82-83).
} 
súmula vinculante 13 constitui, em nosso entendimento, exemplo de atuação do judiciário que extrapola os limites da discricionariedade judicial. Isso não significa que, no mérito, sejamos contra o conteúdo da súmula, mas apenas que, em nosso entendimento, por estar essa matéria reservada à competência do legislativo, adentrar o judiciário nessa seara viola os limites democráticos do direito válido.

\section{REFERÊNCIAS BIBLIOGRÁFICAS}

ALEXY, Robert. A dupla natureza do Direito. Tradução de Alexandre Travessoni Gomes Trivisonno. In: ALEXY, Robert; TRIVISONNO, Alexandre Travessoni Gomes (Org.). Teoria Discursiva do Direito. Rio de Janeiro: Forense Universitária, 2015a, p. 145-159.

ALEXY, Robert. A tese do caso especial. Tradução de Alexandre Travessoni Gomes Trivisonno. In: ALEXY, Robert; TRIVISONNO, Alexandre Travessoni Gomes (Org.). Teoria Discursiva do Direito. Rio de Janeiro: Forense Universitária, 2015b, p. 91-106.

ALEXY, Robert, Theorie der juristischen Argumentation - Die Theorie des rationalen Diskurses als Theorie der juristischen Begründung, Frankfurt a. M.: Suhrkamp, 1978 (reimpressão em 1983; 3. edição 1996)

ALEXY, Robert, Law, Discourse and Time, in: ARSP 64 (1995), 101-110.

ALEXY, Robert, The Special Case Thesis, in: Ratio Juris 12, 4 (1999), 374-384, 378; tradução em português: A Tese do Caso Especial, A. T. G. Trivisonno (trad.), in: Teoria Discursiva do Direito, A. T. G. Trivisonno (org.). Rio de Janeiro: Forense Universitária, 2014, 91-106.

ALEXY, Robert, Diskurstheorie und Rechtssystem, in: Synthesis philosophica 5 (1988), 299310. publicado originalmente em croata, Teorija diskursa i pravni sistem, Maja Uzelac (trans.) Filozofska istrazivanja 20 (1987), 185-194; tradução em português: Teoria do Discurso e Sistema Jurídico, A. T. G. Trivisonno (trad.), in: Teoria Discursiva do Direito, A. T. G.Trivisonno (org.). Rio de Janeiro: Forense Universitária, 2014, 75-89.

ALEXY, Robert, Zum Begriff des Rechtsprinzips, in: Rechtstheorie 1 (1979), 59-87; tradução em português: Sobre o Conceito de Princípio Jurídico, A. T. G. Trivisonno (trad.), in: Teoria Discursiva do Direito, A. T. G. Trivisonno (org.). Rio de Janeiro: Forense Universitária, 2014, 163-198.

ALEXY, Robert, Theorie der Grundrechte, Baden-Baden: Nomos, 1985 (reimpressão Frankfurt a. M.: Suhrkamp, 1986)

ALEXY, Robert, Die Gewichtsformel, in: Gedächtnisschrift für Jürgen Sonnenschein, J. Jickeli, P. Kreutz and D. Reuter (orgs.), Berlin: De Gruyter, 2003, 771-792.

ALEXY, Robert, A Theory of Constitutional Rights, J Rivers (trad.). Oxford: Oxford University Press, 2010, Postscript, 394 f; Teoria dos Direitos Fundamentais, Posfácio, 584. 
ALEXY, Robert, Princípios Formais, A. T. G. Trivisonno (trad.), in: Princípios Formais e Outros Aspectos da Teoria Discursiva do Direito, A. T. G. Trivisonno, A. T. Saliba e M. S. Lopes (org.), Rio de Janeiro 2014, 3-36.

BRASIL. Constituição (1988). Constituição da República Federativa do Brasil. Senado, Brasília, $1988 . \quad$ Disponível em: <http://www.planalto.gov.br/ccivil_03/constituicao/constituicaocompilado.htm>. Acesso em: 04 de junho de 2017.

BRASIL. Supremo Tribunal Federal. Debates que integram a ata da $21^{\mathrm{a}}$ sessão ordinária, realizada em 20 de agosto de 2008. Debates sobre a súmula vinculante $n^{\circ} 13$. Diário de Justiça Eletrônico, Brasília, 12 nov. 2008a, p. 20-24. Disponível em: <http://www.stf.jus.br/arquivo/cms/jurisprudenciaSumulaVinculante/anexo/SUV_11_12_13_ _Debates.pdf $>$. Acesso em: 04 de junho de 2017.

BRASIL. Supremo Tribunal Federal. Súmula vinculante 13. Diário de Justiça Eletrônico, Brasília, 29 ago. 2008c. Disponível em: <http://www.stf.jus.br/arquivo/cms/jurisprudenciaSumulaVinculante/anexo/Enunciados_Sum ula_Vinculante_STF_Completo.pdf>. Acesso em: 04 de junho de 2017.

CAMMAROSANO, Márcio. O princípio constitucional da moralidade e o exercício da função administrativa. Belo Horizonte: Fórum, 2006.

DWORKIN, Ronald. Levando os direitos a sério. Tradução de Nelson Boeira. São Paulo: WMF Martins Fontes, 2002.

DWORKIN, Ronald. Levando os direitos a sério. Tradução de Nelson Boeira. 3. ed. São Paulo: WMF Martins Fontes, 2010.

FIGUEIREDO, Lúcia Valle. Curso de Direito Administrativo. 9. ed. São Paulo: Malheiros, 2008.

HABERMAS, Jürgen, Faktizität und Geltung - Beiträge zur Diskurstheorie des Rechts und des demokratischen Rechtsstaats. Frankfurt a. M.: Suhrkamp, 1992.

HART, Herbert. L. A. The Concept of Law, 2nd ed. Oxfor: Oxford Universtiy Press, 1994.

KELSEN, Hans. Teoria pura do Direito. Tradução de João Baptista Machado. 7. ed. São Paulo: Martins Fontes, 2006.

KELSEN, Hans, Reine Rechtslehre. Einleitung in die rechtswissenschaftliche Problematik, 1. Aufl. Leipzig-Wien: Franz Deuticke 1934.

KHOURI, Alice de Siqueira. Súmula Vinculante no 13 e Moralidade Administrativa: estudo do Nepotismo à luz dos princípios constitucionais da Administração Pública e possível anomia legislativa. Belo Horizonte: PUC Minas, 2017.

RADBRUCH, Gustav. Filosofia do Direito. Tradução de Cabral de Moncada. 6. ed. Coimbra: Arménio Amado, 1997.

ROCHA, Carmen Lúcia Antunes. Princípios constitucionais da Administração Pública. Belo Horizonte: Del Rey, 1994. 
ROCHA, Carmen Lúcia Antunes. Sobre a súmula vinculante. Revista de Informação Legislativa, Brasília, v. 34, n. 133, p. 51-64, jan./mar. 1997. Disponível em: <http://www2.senado.leg.br/bdsf/bitstream/handle/id/193/r133-06.PDF?sequence=4>. Acesso em: 23 ago. 16.

SOBRINHO, Manoel de Oliveira Franco. O princípio constitucional da moralidade administrativa. Belo Horizonte: Del Rey, 1993.

TRIVISONNO, Alexandre Travessoni Gomes; MERLE, Jean-Christophe. A moral e o direito em Kant: ensaios analíticos. 2. ed. Caxias do Sul: Educs, 2015.

TRIVISONNO, Alexandre Travessoni Gomes. O que significa "a injustiça extrema não é direito" crítica e reconstrução do argumento da injustiça no não positivismo inclusivo de

Robert Alexy. Espaço Jurídico Journal of Law, Joaçaba, v. 16, n. 3, p. 97-122, edição especial 2015. Disponível em: <file:///C:/Users/Joao\%20Paulo/Downloads/9676-32110-1-PB.pdf>. Acesso em: 15 ago. 2016.

TRIVISONNO, Alexandre Travessoni Gomes, Princípios Jurídicos e Positivismo Jurídico: As Críticas de Dworkin a Hart se Aplicam a Kelsen, in: Hans Kelsen, Teoria Jurídica e Política, A. T. G. Trivisonno e J. A. De Oliveira (orgs.), Rio de Janeiro: Forense Universitária, 2013, p. 185-212. 